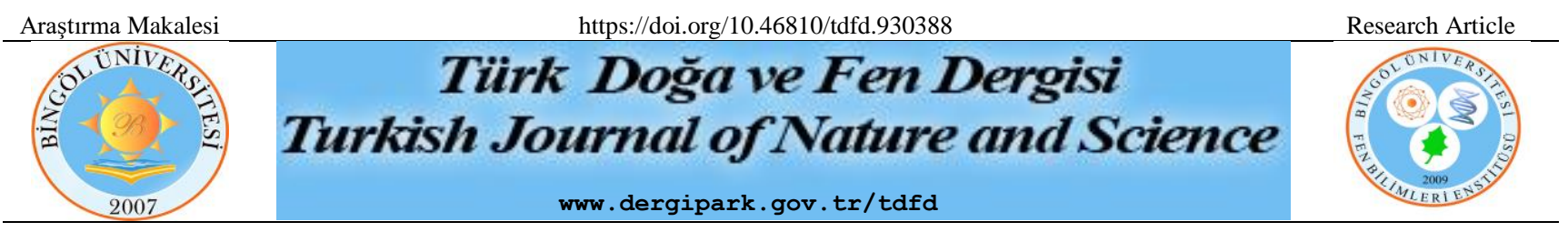

\title{
Antimicrobial Activity of Pigments Extracted from Auxenochlorella protothecoides SC3 against Pseudomonas aeruginosa
}

\author{
Elif ARSLAN ${ }^{1,2}$, Şeymanur ÇOBANOĞLU ${ }^{1,2}$, Ayşenur YAZICI ${ }^{1,2 *}$ \\ ${ }^{1}$ Erzurum Teknik Üniversitesi, Fen Fakültesi, Moleküler Biyoloji ve Genetik Bölümü, Erzurum, Türkiye \\ ${ }^{2}$ Erzurum Teknik Üniversitesi, Yüksek Teknoloji Araştırma ve Uygulama Merkezi (YUTAM), Erzurum, Türkiye \\ Elif ARSLAN ORCID No: 0000-0001-7310-241X \\ Şeymanur ÇOBANOĞLU ORCID No: 0000-0002-2805-0523 \\ Ayşenur YAZICI ORCID No: 0000-0002-3369-6791
}

*Corresponding author: aysenur.ozdemir@erzurum.edu.tr

(Alınış: 30.04.2021, Kabul: 12.10.2021, Online Yayınlanma: 31.12.2021)

\section{Keywords} Auxenochlorella protothecoides, Antimicrobial, Pigment

\begin{abstract}
Nowadays, natural microbial pigments are emerging as potential candidate therapeutic agents that can be used in antibiotic resistance. In this paper, we report the antimicrobial activity of green algae pigments. Green algae SC3 isolate was isolated from soil in Erzurum. Pigments extracted by methanol: dimethyl sulfoxide solvents were partially characterized by Thin Layer Chromatography (TLC), UV-Absorbance, and Fourier-transform infrared spectroscopy (FTIR). The antimicrobial activity of pigments was determined with agar well diffusion and microbroth assays against Pseudomonas aeruginosa (ATCC 27853 and clinic isolate), Staphylococcus aureus (ATCC 25923) and Escherichia coli (ATCC 25922). To identify green algae, total DNA was isolated and both 18S rRNA and 16S rRNA for the chloroplast genome were amplified using universal primers. Thus, this alga was identified as Auxenochlorella protothecoides and submitted to Genbank (Accession number: MW139225 and MW063613). According to our results, the best antimicrobial activity was recorded against $P$. aeruginosa. Our results show for the first time the antimicrobial activity of the total pigments from $A$. protothecoides green algae.
\end{abstract}

\section{Auxenochlorella protothecoides SC3'ten Ekstre Edilen Pigmentlerin Pseudomonas aeruginosa'ya karşı Antimikrobiyal Aktivitesinin Değerlendirilmesi}

\section{Anahtar Kelimeler Auxenochlorella protothecoides, Antimikrobial, Pigment}

\begin{abstract}
Öz: Günümüzde, doğal mikrobiyal pigmentler, antibiyotik direncinde kullanılabilecek potansiyel aday terapötik ajanlar olarak karşımıza çıkmaktadır. Bu çalışmada, yeşil alg pigmentlerinin antimikrobiyal aktivitesi gösterilmiştir. Yeşil alg SC3 izolatı Erzurum'da topraktan izole edildi. Metanol:dimetil sülfoksit ile ekstrakte edilen pigmentler kısmi olarak ince tabaka kromotografisi (TLC), UV-Absorbans1 ve fourier-transform k1zılötesi spektroskopi (FTIR) yöntemleri ile karakterize edildi. Pigmentlerin antimikrobiyal aktivitesi, Pseudomonas aeruginosa (ATCC 27853 ve klinik izolat1), Staphylococcus aureus (ATCC 25923) ve Escherichia coli (ATCC 25922)'ye karşı agar difüzyon ve mikroplak deneyleri ile belirlendi. SC3 izolatını tanımlamak için total DNA izole edildi ve hem 18S rRNA bölgesi hem de kloroplast genomu için 16S rRNA bölgesi evrensel primerler kullanılarak çoğaltıldı. Bu şekilde, SC3 izolatı Auxenochlorella protothecoides olarak tanımlandı ve Genbank'a kaydedildi (Erişim numarası: MW139225 ve MW063613). Çalışmamıza göre, en iyi antimikrobiyal aktivite $P$. aeruginosa'ya karşı olduğu belirlenmiştir. Sonuçlarımız, $A$. protothecoides yeșil alginden elde edilen total pigmentlerin antimikrobiyal aktivitesini ilk kez göstermektedir.
\end{abstract}

\section{INTRODUCTION}

Antibiotic resistance is one of the biggest threats to global health today. The emergence of new resistance mechanisms poses a major threat to global health, causing high medical costs and mortality. With the increasing bacterial resistance to antibacterial agents and multidrug resistance, the development of new antimicrobial agents and improvement of existing antimicrobial agents is of global importance [1]. One of the antibiotic resistant bacteria is $P$. aeruginosa. It 
responsible for nosocomial infections and exhibits resistance to a variety of antibiotics [24]. Urgent treatment option or new antibiotics are required for the treatment of this bacterium.

Microalgae are microscopic microorganisms that can live in all ecosystems, can perform photosynthesis, and can be found in single-cell, colony, or filamentous forms [2-4]. Microalgae are of great interest as a promising resource for the sustainable production of various bioactive compounds. It contains algae biomass, pigments, proteins, essential fatty acids, polysaccharides, vitamins, and minerals [5].

Compound screenings of microalgae have been carried out since 1950. In recent years, bioactive agents produced by microalgae have been used for therapeutic purposes. Many microalgae extracts or extracellular products have been found to have antimicrobial, antifungal, antibiofilm, antiprotozoal, antiplasmodial, antioxidant, anti-inflammatory, antiviral, and antitumor effects [2,3] Studies have shown that microalgae compounds and their derivatives can be candidates for antimicrobial drug development due to their ability to fight pathogenic bacteria.

A. protothecoides, formerly known as Chlorella protothecoides, is eucaryotic microalga that supports mixotrophic metabolism. In this study, the pigments from A. protothecoides SC3 isolated from soil identified using both 16S rRNA for chloroplast and 18S rRNA gene. The pigments were partially characterized using TLC, UV-Abs, and FTIR. To investigate the antimicrobial potential of $A$. protothecoides pigments against bacterial pathogens, we extracted total pigments from biomass of solid culture. Inhibition zone obtained from agar-well diffusion assay and minimum inhibitory concentration (MIC) were calculated. In light of the information obtained as a result of the study, the pigments of $A$. protothecoides SC3 demonstrate antimicrobial activity against $P$. aeruginosa.

\section{MATERIALS AND METHODS}

\subsection{Materials and Bacterial Strains}

All chemicals were analytical grade and mediums were purchased from Oxoid (England). Pseudomonas aeruginosa (ATCC 27853 and clinic isolate of our laboratory stock), Staphylococcus aureus (ATCC 25923) and Escherichia coli (ATCC 25922) were used as the reference bacterial pathogens to investigate the antimicrobial activity.

\subsection{Isolation of Pigment Producer Algal Isolate}

The soil sample is collected in November 2019 from the Erzurum city in Turkey. 0,5 gr of soil sample was diluted in $10 \mathrm{~mL}$ sterile water and serial dilution was made. 100 $\mu \mathrm{L}$ of 10-4 dilution sample was seeded on the YEPC agar (Yeast extract 5,0 g/L; D(+) Glucose 20,0 g/L; Chloramphenicol 0,1 g/L; Agar-agar 14,9 g/L) plate. After 7 days of incubation at $25{ }^{\circ} \mathrm{C}$, colonies were picked. Green colonies were examined under a light microscope and selected as a eukaryotic alga for further experiments.

\subsection{DNA isolation, $16 \mathrm{~S}$ and $18 S$ rRNA PCR and Molecular Identification}

The 18S rRNA region was amplified using universal ITS primers (ITS1:5'TCCGTAGGTGAACCTGCGG3'; ITS4: 5'TCCTCCGCTTATTGATATGC3'). The 16S rRNA region in the chloroplast genome was amplified using universal $27 \mathrm{~F}$ and $1392 \mathrm{R}$ primers (27F: 5'AGAGTTTGATCMTGGCTCAG3'; 1392R: 5'ACGGGCGGTGTGTRC3'). The PCR contained $5 \mu \mathrm{L}$ of PCR buffer, $40.2 \mu \mathrm{L}$ of nuclease-free water, $0.7 \mu \mathrm{L}$ dNTP $(25 \mathrm{mM}), 0.8 \mu \mathrm{L}$ of each primer, and $2 \mu \mathrm{L}$ of DNA $0,5 \mu \mathrm{L}$ of Taq polymerase (Dream Taq, Thermo). Thermal cycling followed the following steps: $2 \mathrm{~min}$ at $95^{\circ} \mathrm{C}, 30$ cycles of $94^{\circ} \mathrm{C}$ for $45 \mathrm{sec}, 55^{\circ} \mathrm{C}$ for $45 \mathrm{sec}$ and $72^{\circ} \mathrm{C}$ for $1 \mathrm{~min}$, a final extension at $72^{\circ} \mathrm{C}$ for $10 \mathrm{~min}$. After PCR, the amplicons were visualized in $100 \mathrm{~mL} 1 \%$ $(\mathrm{w} / \mathrm{v})$ agarose gel with $3 \mu \mathrm{l}$ ethidium bromide (5 $\mathrm{mg} / \mathrm{mL}$ ). Then, PCR products were purified with a PCR purification kit (Invitrogen) and sequenced in both directions.

\subsection{Pigment Extraction}

Pigment production was carried out in MYEB (10 g/L glucose; $5 \mathrm{~g} / \mathrm{L}$ peptone; $3 \mathrm{~g} / \mathrm{L}$ malt extract; $3 \mathrm{~g} / \mathrm{L}$ yeast extract $\mathrm{pH}: 6,3)$ medium. The extraction of pigments from isolated algae was made according to [6], with modifications. Briefly, $1 \mathrm{~g}$ of bacterial cell pellet and methanol: dimethyl sulfoxide (DMSO) $(2: 1)$ solvent was transferred into the tube. Cells were broken by a homogenizer (Qiagen). Then, cells were harvested by centrifugation at $9.000 \mathrm{rpm}$ for 10 minutes. The supernatant was gathered.

\subsection{Thin-layer chromatography (TLC), UV- Absorbance, and FT-IR}

The extracted pigments were implemented on the aluminum-supported TLC plates (Merck, silica gel 60 F254). Methanol: dichloromethane $(7: 3, \mathrm{v} / \mathrm{v})$ was used as a solvent system. After equilibration, the TLC plate was extincted and air-dried. Afterward, Rf (retention factor) values were calculated.

Absorbance spectrum and fourier transform infrared spectroscopy (FTIR) was executed as to [7] with some modifications. Absorbance was scanned using a spectrophotometer (Multiskan GO, Thermo) between 300 and $800 \mathrm{~nm}$ to attain the absorption wavelength related to this pigment. Initial scanning, methanol:DMSO (2:1) was used as blank

Fourier Transform Infrared-Attenuated Total Reflectance (FTIR-ATR, Bruker VERTEX 70V) spectroscopy was used to detect functional groups of pigments. Spectra were measured within the frequency range $500-4000 \mathrm{~cm}^{-}$ 


\subsection{Agar-well Diffusion Assay}

Former screening of antimicrobial composition from bacteria was made using agar-well diffusion assay [8]. In brief, 0.5 McFarland (1x105 CFU mL-1) pathogen bacterial suspension was overlaid Mueller Hilton Agar (MHA) medium and made a hole using $6 \mathrm{~mm}$ cork borer. $150 \mu \mathrm{L}$ of pigment was seeded onto wells. The inhibition zone was measured to detect the antimicrobial effects.

\subsection{Minimum Inhibitory Concentration (MIC)}

Different concentrations of pigments $(0,5-512 \mu \mathrm{g}$ mL- 1$)$ and $0,5 \mathrm{McF}$ arland bacterial cells were added to the $96-$ well plate. The plate was incubated for 24 hours at $37^{\circ} \mathrm{C}$. The lowest concentration with no growth was recorded for pathogens as MIC [8].

\section{RESULTS AND DISCUSSION}

\subsection{Molecular Characterization of Algal Isolate}

To identify microalgae SC3 isolate, 18S rRNA was amplified using universal ITS1 and ITS4 primers. In this way, 647 base pairs were amplified and registered in the NCBI database with the number MW139225. Furthermore, 1,296 base pairs of chloroplast 16S rRNA region was multiplied using other universal $27 \mathrm{~F}$ and $1392 \mathrm{R}$ primers. This region was registered in NCBI GenBank with the accession number MW063613.

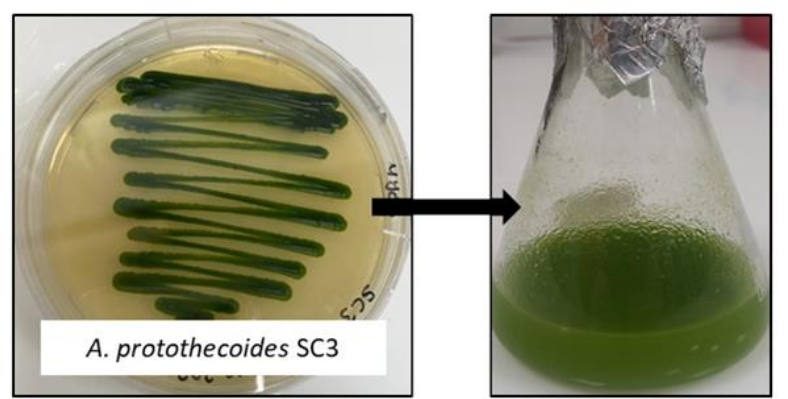

Figure 1. The petri images and liquid culture of A. protothecoides SC3 isolate in MYEB medium.

Microalgae can survive in a wide range of environmental habitat. Especially, they are predominantly found in fresh and marine water [9]. Interestingly, the purification of $A$. protothecoides from soil samples collected from Erzurum city was carried out in our screening of antimicrobial molecule producing isolates.

A. protothecoides is a biotechnologically important species. In particular, it is a potential resource in biofuel production due to its high lipid content [10]. Furthermore, this alga has antifungal activity against $A$. niger, A. alternata and $P$. expansum and extract of $A$. protothecoides has a stronger antioxidant activity [6].

\subsection{Characterization of Pigments}

The pigments of $A$. protothecoides SC3 were elucidated using TLC, UV-Abs and FT-IR. The four pigments were detected in the TLC plate and Rf values of them were calculated. Green, blue, yellow and brown spots shown in Figure 2 demonstrated that A. protothecoides SC3 have different types of pigments. The $\mathrm{Rf}$ value of green, blue, yellow and brown pigments was 0,$97 ; 0,89 ; 0,72$; 0,64 ; respectively.

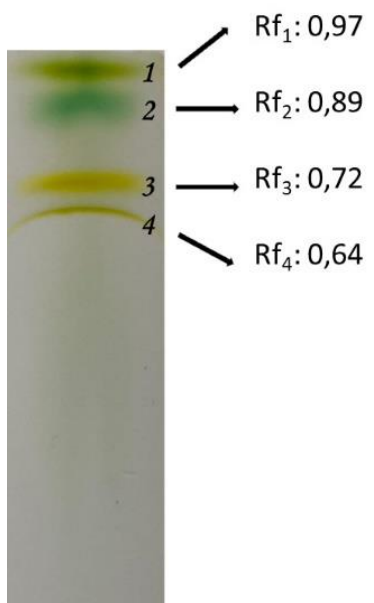

Figure 2. TLC images of A. protothecoides SC3 pigments

Microbial pigments are colorful compounds produced by bacteria, fungi, and algae. Pigments can be used for food additives, textile, cosmetic dyes and medical applications in the industry [11-13]. Carotenoid, which is a highly valuable bioactive molecule stored in microalgae, has antimicrobial properties. Carotenoids are natural pigments that show a multi-spectrum color band, including bright yellow (lutein), orange (astaxanthin), red (lycopene) [14].

UV- absorbance spectrum of A. protothecoides SC3 pigments was measured with spectrophotometer at a wavelength region of 300-800 nm. As shown in Figure 3 , the maximum absorbance value is $440-450 \mathrm{~nm}$ and the second maximum absorbance is 665-675 $\mathrm{nm}$. In addition, there are other picks in 330-340 nm and 620$630 \mathrm{~nm}$. Each pigment gives a different absorbance spectrum [15]. Thus, the A. protothecoides pigments could possibly be chlorophyll a, chlorophyll $\mathrm{b}$ and carotenoid.

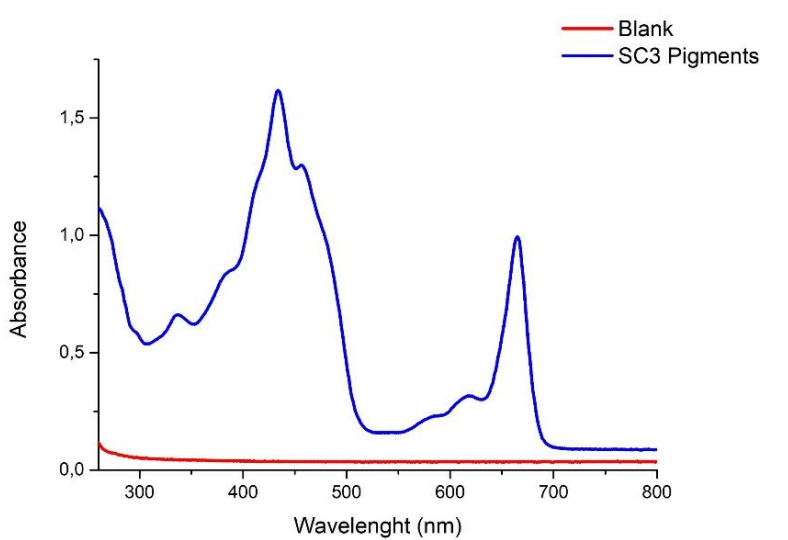

Figure 3. UV-Absorbance spectrum of A. protothecoides SC3 pigments 
FTIR is a technique used in the partial characterization of microbial pigments. The pigment composition of $A$. protothecoides SC3 was determined using a FTIR-ATR spectrum of pigment extract and FTIR spectra result from the contributions of all pigments. Several major peaks at 3330, 2925, 2850, 1105, 1040 was observed from transmission spectrum. As shown in Figure 4, FTIR spectrum of the total pigments indicates the presence of high density chlorophyll pigment [16].

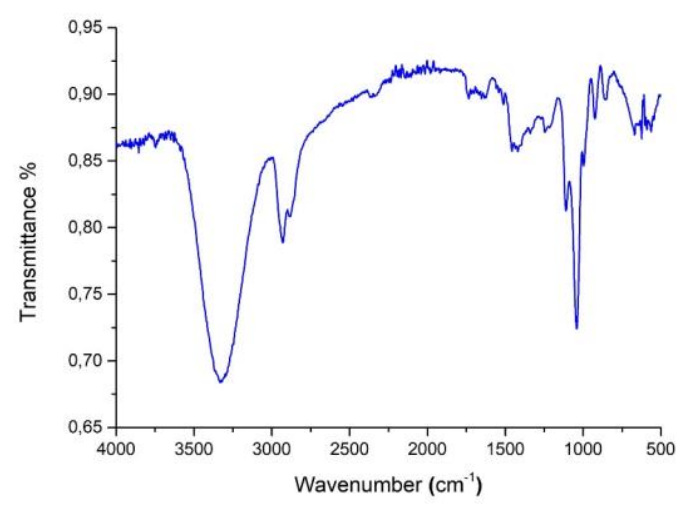

Figure 4. FTIR spectrum of A. protothecoides SC3 pigments

\subsection{Antimicrobial Activity of Pigments}

The methanol:DMSO extract of A. protothecoides SC3 isolate was tested. To determine the antimicrobial activity of $A$. protothecoides SC3 pigments, the inhibition zone was measured against all bacterial pathogens. Inhibition zone diameters were determined as $15 \mathrm{~mm}$ and $20 \mathrm{~mm}$ against $P$. aeruginosa ATCC 27853 and clinical isolate, respectively. Furthermore, $8 \mathrm{~mm}$ diameter zone was measured against $E$. coli (ATCC25922). It did not show antimicrobial activity against $S$. aureus (ATCC 25923).
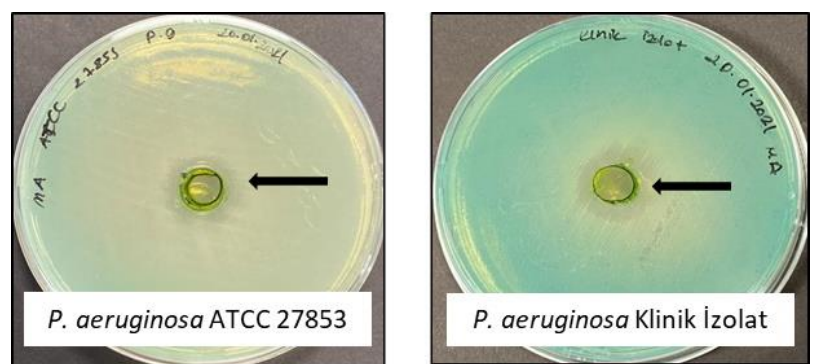

Figure 5. Agar-well diffusion assay images.

MIC value is also determined with broth microdilution assay. MIC was defined as the lowest concentration of pigment compounds that inhibited the visible growth of a microorganism after $24 \mathrm{~h}$ incubation with minimum concentration of pigment compounds. MIC value against $P$. aeruginosa reference and clinical isolate is $>=64 \mu \mathrm{g}$ $\mathrm{mL}-1$ and $64 \mu \mathrm{g} \mathrm{mL}-1$, respectively. Furthermore, MIC values against $E$. coli and $S$. aureus were determined. MIC value of SC3 total extract is $>128 \mu \mathrm{g} / \mathrm{mL}$ against $E$. coli. In contrast, the MIC value for $S$. aureus was found to be $>512 \mu \mathrm{g} / \mathrm{mL}$. These results demonstrated that pigments of $A$. protothecoides SC3 shows antibacterial effect against $P$. aeruginosa. Another interesting case is that when the A. protothecoides SC3 isolate grows in the dark, the resulting pigments show more antimicrobial properties (data not shown). The results of MIC value revealed that total extract of SC3 isolate had more antibacterial effect on Gram-negative bacteria compared to Gram-positive types. Considering that antibiotics used against Gram negative bacteria, especially $P$. aeruginosa, have decreased, SC3 pigments appear to be a potential application area.

Green algae of the genus Chlorella contain many natural metabolites such as anticancer, antifungal, antioxidant and antibacterial compounds [17]. These bioactive compounds carotenoids, sulfated polysaccharides, sterols, PUFAs (n-3) fatty acids, canthaxanthin, astaxanthin, peptide, oleic acid, eicosapentaenoic acid (EPA), zeaxanthin, violaxanthin, lutein, phenolic, terpenoids, alkaloids, phytol, phenol [18]. The antibacterial properties of microalgae have been known since the 1940s. Since the emergence of the antibiotic resistance problem, algae metabolites have started to attract attention again [19].

Sampathkumar et al. (2019) reported that lutein isolated from Chlorella pyrenoidosa showed antibiofilm and quorum sensing inhibitor properties [14]. Vehabi et al. (2020) showed that methanol extract of $A$. protothecoides has antifungal and antioxidant activity [6].

The most important type of carotenoid found in $A$. protothecoides microalgae pigments is lutein. Lutein content increases under stress conditions [20]. However, Indhu and Iyer (2017) reported that lutein isolated from Chlorella spp. has no antibacterial activity against Staphylococcus and E.coli using agar diffusion assay [21]. Similar findings were observed in our study against S. aureus for the total pigment of SC3 isolate.

A. protothecoides is also important as a species of algae with very high lipid content. The lipid content is related to the nitrogen and glucose source [22,23]. The antimicrobial molecule content can be increased by optimizing the medium. Özçimen (2017) showed the antifungal activity of microalgae oil isolated from Chlorella protothecoides against fungal microorganisms such as Botrytis cinerea and Aspergillus niger [17].

\section{CONCLUSION}

A. protothecoides is a green microalga that is a biotechnological significant characteristic. In the current study, we isolated A. protothecoides SC3 isolate from soil and its pigment was extracted with methanol: DMSO solvent. The antimicrobial activity of pigments against $P$. aeruginosa, a Gram-negative bacteria, indicates that this algae species is an important species to antimicrobial resistance. However, further characterization studies are needed for these pigments. 


\section{REFERENCES}

[1] Coates A, Hu Y, Bax R, Page C. The future challenges facing the development of new antimicrobial drugs. Nat Rev Drug Discov 2002;1:895-910.

[2] Amaro H, Guedes A, Malcata F. Antimicrobial activities of microalgae: an invited review. Sci against Microb Pathog Commun Curr Res Technol Adv 2011:1272-80.

[3] López Y, Soto SM. The Usefulness of Microalgae Compounds for Preventing Biofilm Infections. Antibiotics 2019;9:9.

[4] Asker D, Awad TS. Isolation and characterization of a novel lutein-producing marine microalga using high throughput screening. Food Res Int 2019;116:660-7.

[5] Mourelle M, Gómez C, Legido J. The Potential Use of Marine Microalgae and Cyanobacteria in Cosmetics and Thalassotherapy. Cosmetics 2017;4:46.

[6] Vehapi M, Koçer AT, Yılmaz A, Özçimen D. Investigation of the antifungal effects of algal extracts on apple-infecting fungi. Arch Microbiol 2020;202:455-71.

[7] Kendirlioglu G, Kadri Cetin A. Effect of different wavelengths of light on growth, pigment content and protein amount of chlorella vulgaris. Fresenius Environ Bull 2017;25:7974-80.

[8] Balouiri M, Sadiki M, Ibnsouda SK. Methods for in vitro evaluating antimicrobial activity: A review. J Pharm Anal 2016;6:71-9.

[9] Rojas V, Rivas L, Cárdenas C, Guzmán F. Cyanobacteria and Eukaryotic Microalgae as Emerging Sources of Antibacterial Peptides. Molecules 2020;25.

[10] Polat E, Altınbaş M. Optimization of Auxenochlorella protothecoides lipid content using response surface methodology for biofuel production. Biomass Convers Biorefinery 2020.

[11] Neha T, Shishir T, Ashutosh D. Fourier transform infrared spectroscopy (FTIR) profiling of red pigment produced by Bacillus subtilis PD5. African J Biotechnol 2017; 16:1507 - 12.

[12] Ramesh C, Vinithkumar NV, Kirubagaran R, Venil CK, Dufossé L. Multifaceted applications of microbial pigments: Current knowledge, challenges and future directions for public health implications. vol. 7. 2019.

[13] Sen T, Barrow CJ, Deshmukh SK. Microbial pigments in the food industry-challenges and the way forward. Front Nutr 2019;6:1-14.

[14] Sampathkumar SJ, Srivastava P, Ramachandran S, Sivashanmugam K, Gothandam KM. Lutein: A potential antibiofilm and antiquorum sensing molecule from green microalga Chlorella pyrenoidosa. Microb Pathog 2019;135:103658.

[15] Redmond S. Gracilaria Culture Handbook for New England Gracilaria Culture Handbook for New England 2017.

[16] Ahmed JK. Effect of Chlorophyll and Anthocyanin on the Secondary Bonds of Poly Vinyl Chloride (PVC). Int J Mater Sci Appl 2015;4:21.
[17] Özçimen D. Chlorella protothecoides Mikroalg Yağının Botrytis cinerea ve Aspergillus niger Küflerine Karşı Antifungal Etkisinin İncelenmesi. Tekirdağ Ziraat Fakültesi Derg 2018;15:45-52.

[18] Vaz B da S, Moreira JB, Morais MG de, Costa JAV. Microalgae as a new source of bioactive compounds in food supplements. Curr Opin Food Sci 2016;7:73-7.

[19] Jyotirmayee P, Sachidananda D, Basanta K Das. Antibacterial activity of freshwater microalgae: A review. African J Pharm Pharmacol 2014;8:809_ 18.

[20] Wei D, Chen F, Chen G, Zhang XW, Liu LJ, Zhang $\mathrm{H}$. Enhanced production of lutein in heterotrophic Chlorella protothecoides by oxidative stress. Sci China, Ser C Life Sci 2008;51:1088-93.

[21] Indhu, R., Iyer, P., 2017. Extraction, anti-oxidant, anti-bacterial and anti-cancer activity of lutein from microalgae.Int.J.Curr.Res.Biosci.Plantbiol. 4(9): 42-46.

[22] Fei Q, Fu R, Shang L, Brigham CJ, Chang HN. Lipid production by microalgae Chlorella protothecoides with volatile fatty acids (VFAs) as carbon sources in heterotrophic cultivation and its economic assessment. Bioprocess Biosyst Eng 2015;38:691-700

[23] Shen Y, Yuan W, Pei Z, Mao E. Heterotrophic culture of Chlorella protothecoides in various nitrogen sources for lipid production. Appl Biochem Biotechnol 2010;160:1674-84.

[24] Pang, Z., Raudonis, R., Glick, B. R., Lin, T. J., \& Cheng, Z. (2019). Antibiotic resistance in Pseudomonas aeruginosa: mechanisms and alternative therapeutic strategies. Biotechnology advances, 37(1), 177-192. 